\title{
GASTRONOMIC DISCOURSE OF “TEA DRINKING” CULTURE IN UZBEK AND ENGLISH LANGUAGES FROM THE POINT OF CONSUMPTION
}

\author{
Sayyora Yuldashovna Pulatova
}

Termez State University, Termez, Uzbekistan

\section{ABSTRACT}

In this paper, linguistic features of tea drinking in Uzbek and English languages from the consumption point of view are studied. Based on gastronomic discourse theory on comparative and cross-cultural methods as a special type of communication associated with the state of food resources and the processes of consumption by the way the people interact with tea. Moreover, compared with tea drinking traditions of Uzbek and English peoples' communication, examples are comparatively given as well. The research work can provide theoretical and practical basis for the further research.

KEYWORDS: - Gastronomic discourse, the consumer and cultural dominants, nutrition, participants, food consumption, teahouse, the chaikhana (teahouse) carpets and sofas, element of local traditions.

\section{INTRODUCTION}

Speaking about gastronomic discourse, it should be noted that it is studied as a genre of institutional communication since it operates within the framework of the Institute of Culinary Arts. We agree with the opinion of A.V. Olyanich that he defines gastronomic discourse as a special type of communication associated with the state of food resources and of their processing and consumption [2].

According to N.P. Golovnitskaya, the goal of gastronomic discourse is to form both food preferences of the consumer and cultural dominants (table etiquette, rules of behavior at the table, etc.) associated with maintaining life through food consumption. In other words, the goal of this type of discourse is the formation of values, first of all, proceeding from the main task of gluttonic communication: nutrition is one of the necessary conditions for biological survival, since in order to live, first of all, you need to eat; participants, in her opinion, are: an agent, that is, a person with extensive experience, skills, abilities, knowledge in the field of gastronomy, or an employee of a catering establishment (for example, a waiter, restaurateur, bartender) and a client, that is, a person intending that either cook, or a visitor to a catering establishment [1].

Tea culture is defined by the way tea is made and consumed, by the way the people interact with tea, and by the aesthetics surrounding tea drinking.

\section{THE MAIN FINDINGS AND RESULTS}

Based on the foregoing, from the point of view of consumption, as an example of a gastronomic character, we can take the contexts associated with the teahouse characteristic of the Uzbek national color: So, the chaikhana (teahouse) is the same unshakable element of local traditions, like tea 
CURRENT RESEARCH JOURNAL OF PHILOLOGICAL SCIENCES 2(9): 76-79,

September 2021

DOI: https://doi.org/10.37547/philological-crjps-02-09-16

ISSN 2767-3758

(C2021 Master Journals

Crossref do

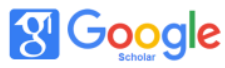

Accepted25 $5^{\text {th }}$ September, 2021 \& Published $30^{\text {th }}$ September, 2021

itself. Public life here is concentrated in mosques, in the bazaar and, naturally, in the teahouse. Here they simply communicate and negotiate, relax and share news, have breakfast and dinner, discuss the problems of life and the world order.

They choose a place for a teahouse, usually somewhere in the shade of trees and close to the water, which, along with tea, should make the conversation calm and non-vain. The setting of the teahouse is quite traditional - low tables are surrounded by the same low and always covered with carpets and sofas. Somewhere in the corner, the owner or the servant fusses about, and the main place is occupied, as one would expect, by the hearth, over which water is boiled or food is being prepared, and the teapots themselves. The rituals accompanying tea drinking are rather complicated and incomprehensible to the uninitiated, so it is easier to observe the locals and do as they do - you can be sure that they will also appreciate such a respectful attitude to their customs [4].

When entering a house or teahouse, you should take off your shoes. The style of clothing is quite democratic, but when visiting cult places, you should not wear excessively open or short clothes. Despite everything, it is not recommended to wear shorts, especially in rural areas [4].

As you can see, the participants are the owner or the servant and the basic rules for accepting visitors to the teahouse.

Now let's give examples from artistic context with lexemes tea, tea drinking, teahouse in Uzbek and English languages.

Examples of Uzbek traditions of drinking tea:

1)Эртаси куни чойхонага ош буюртириб, ошуқатиқ бўлиб юрган танишларига қўнғироқ қилиб чиқди.Ош устида муддаосини маълум қилмоқчи бўлганди...( The next day he ordered osh (palov) in the chaihona (the teahouse) and called his acquaintances who were having a hard time).

Ош хам тайёр бўлди. Бироқ Рашиднинг мақсадидан Эркин орқали хабар топган "улфат" ларнинг бирортаси шу куни чойхонага яқинлашмади. ... (The osh was also ready. However, none of the "friends" who learned of Rashid's intentions through Erkin approached the chaihona that day.... (Bakhtiyor Mansurov, "Let the young man go", Gulistan -2007, p. 36).

2) Хурмат бўлса, шунчалик бўлар.Эркак кишининг сўзи ерда қолгунча шайтоннинг бўйни узилгани яхши, дейдилар-ку ахир.Танишим берган адрес бўйича йўлга отландим.Вилоятнинг тайинланган туманига етиб бориб, у ишлайдиган базани суриштирдим... Шунда туман дехқон бозоридаги чойхонага кириб дардимни баён қилдим, кимни йўқлаб келганимни тушунтирдим.Четдаги даврада ўтирганлардан бири "сиз бир пиёла чой ичиб туринг. Мен хозир суриштираман”, деганча чиқиб кетди... ...(Бахтиёр Мансуров,"Мақтанганнинг уйига" Гулистон 2007 йил 27-бет), [3]. ( If there is respect, it will be so. It is said that it is better for a man to cut off the devil's neck before his words remain on the ground. I went to the address given by my acquaintance. Then I went to the chaihona in the district farmers' market and expressed my grief I explained who I was visiting. One of the people sitting in the circle said, "You have a cup of tea. I'm asking now, "he said ....)

3) Шунда отини йўқотган киши чойхонага келиб қолибди.Уни хамма одамлар "Хой, бери келинг, бери келинг”, деб чувиллашиб чақириб қолишибди.Буни ўғриларнинг жосус аёрлари кўриб турган экан. Чойхонадаги одамлар ундан отини қандай йўқотганини ва қандай қилиб топганинни сўрабдилар.Бу одам воқеани бирбир гапириб берибди ( “Авом фолчи”)[5].(Then 
CURRENT RESEARCH JOURNAL OF PHILOLOGICAL SCIENCES 2(9): 76-79,

September 2021

DOI: https://doi.org/10.37547/philological-crjps-02-09-16

ISSN 2767-3758

(C2021 Master Journals

Crossref do

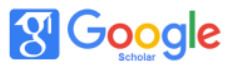

Accepted25 $5^{\text {th }}$ September, 2021 \& Published $30^{\text {th }}$ September, 2021

the man who had lost his horse came to the chaihona. All the people shouted at him, "Hey, come on, come on, come on." People in the chaihona asked him how he had lost his horse and how he had found it.)

Discussing about English tea drinking culture we can say that throughout the years, various people have had different opinions on tea in Britain. However, they can all agree on the fact that tea will always be a part of the British tea culture. It seems that a cup of tea or a "cuppa" as they call it, solves everything from sickness to crisis....

Tea and the ceremony of British tea drinking was a symbol of civilizing and sanitizing Asian products within British daily life - of both the exotic and the domestic.

In Great Britain most of the time, tea is brewed directly in a mug with the tea bag. Then, milk and sugar are added if needed. Most British people drink a lot of tea this way, starting with the first cup of the day upon waking. Tea often comes with a biscuit, a sandwich or a slice of cake....

A typical afternoon tea is usually loose tea in a teapot with milk and sugar. Along with the tea, you will find traditional British style sandwiches such as cucumber, egg and cress, tuna or ham....

Now that, we should look paradigm of the tea drinking culture in the English language from the consumption point of view:

1)Nadia Sinel, 20, is a big fan of green tea and bubble tea. "Black teas are too strong and in some cases quite bitter, and then you have to put a lot of sugar or honey in to sweeten it," freelance songwriter Nadia Sinel, 20, tells the BBC. "I prefer green tea as it's more of a light floral taste and there's less caffeine."

2) Ms Sinel thinks young people like to drink green tea because of its health benefits and the fact "it tastes nicer", and other popular drinks include bubble tea - a beverage that originated in Taiwan in the late 1990s - and a lemonade drink from the US called Calypso.

3)...Known for drinking tea from breakfast until dinner (and sometimes even after), Pooh has a certain appreciation for its soothing qualities, as well as the fact that it's something you can, in fact, put honey in. As Piglet says, tea, as much as honey, is the ingredient that always help Pooh feel like Pooh again.

4)Rosemary turned. She saw a little battered creature with enormous eyes, someone quite young, no older than herself, who clutched at her coatcollar with reddened hands, and shivered as though she had just come out of the water.

"M-madam," stammered the voice. "Would you let me have the price of a cup of tea?"

"A cup of tea?" There was something simple, sincere in that voice; it wasn't in the least the voice of a beggar. "Then have you no money at all?" asked Rosemary.

"None, madam," came the answer.

\section{Conclusion}

Thus, we tried to describe the characteristic linguapragmatic features of the "tea drinking" culture in Uzbek and English languages, especially using the examples of tea drinking process, which are the cultural dominant of both Uzbek and English peoples, where conversations are held through the food eating from the gastronomic point of view, that is, the discourse in the mentioned languages related to food consumption.

\section{REFERENCES}

1. Golovnitskaya N.P. Linguocultural characteristics of the German-language 
CURRENT RESEARCH JOURNAL OF PHILOLOGICAL SCIENCES 2(9): 76-79,

September 2021

DOI: https://doi.org/10.37547/philological-crjps-02-09-16

ISSN 2767-3758

(C)2021 Master Journals

crossref do) 801 Google

Accepted25 $5^{\text {th }}$ September, 2021 \& Published 30 th September, 2021

gastronomic discourse: author. dis. ... Cand. philol. Sciences: 10.02.04./ N.P. Golovnitskaya.

- Volgograd, 2007 -p.75

2. Olyanich A.V. Presentation theory of discourse: Monographiya. - Volgograd: Paradigm, 2004 .p.507.

3. Mansurov Bakhtiyor. - Kayot - bu sinov. Guliston -2007 yil.

4. Internet materials.

5. O'zbek khalq ertaklari. 3-vol. Tashkent-2007, p.16.

6. Винни-Пух / Winnie-the-Pooh (Milne, 2005)

7. Wikipedia, the free encyclopedia

8. https://www.teabloom.com - How Does a British Tea Culture Look Like? By Sonja Masnikosa Tea Knowledge / September 27, 2018.

9. The Art of Tea: Late Victorian Visual Culture and the Normalization of an International National Icon by Emalee Beddoes., School of Art History, Film and Visual Studies, College of Arts and Law University of Birmingham ,January 2014. p.37.

10. Mary-Ann Russon, BBC News, 18 October 2019., Hatier dossier 1.pdf.,p 4

11. Saidakbarova, S. P. (2020). Fruit And Vegetables... Exploring Gastronomic Idioms In English And Uzbek (The Linguo-Cultural Analysis Of English And Uzbek Phraseological Units With The Components Fruit And Vegetables). CURRENT RESEARCH JOURNAL OF PHILOLOGICAL SCIENCES (2767-3758), 1(01), 24-32.

12. Usmanova, S. R., \& Ismatullayeva, N. R. (2020). Expression Of Lacunas In Comparative Study Of Kinship Terms In Chinese And Uzbek Languages. Solid State Technology, 63(6), 4974-4985.

13. https://www.historicuk.com/CultureUK/Afternoon-Tea.

14. http://www.katherinemansfieldsociety. 